\title{
Language of the Hand in Indo-European Idioms
}

\author{
Doina BUTIURCA \\ Department of Applied Linguistics \\ Faculty of Technical and Human Sciences, Târgu-Mureş \\ Sapientia Hungarian University of Transylvania \\ butiurcadoina@yahoo.com
}

\begin{abstract}
The research starts from the assertion that there is an interdependent rapport between cultural forms and the experiential field, necessary for the dynamics of cultural development. The general objective of our approach is the development of a system of relations ordered by human experience for linguistic vitality (of a language/group of [kindred] languages) in the mental and cultural fields. Particular/experiential takes on the concepts of "right"/"left", the systemic extension of significances in linguistics, religion, moral mentality, and culture of peoples of the world stand as secondary objectives of the research. Application is made to pan-Latin languages, Hungarian, and English. Synchronic and diachronic analysis, contrastive method, and cognitive approach are but a few of the research methods. The first of the conclusions to be drawn is that the diachronic dynamics of a culture is ensured by the systemic relations between human experience, language, mentality, and others.
\end{abstract}

Keywords: culture, language, pan-Latin, English

The premises of our study allowed us to remark that at least two types of relationships can be established between language and cultural pattern: 1 . logical relations always based on the dialectic of correlation and/or opposition and 2. analogical relations.

Idioms having parts of the human body as a referent are an illustration of the idea that the human alter-ego has risen above his primary meaning, that of man as an entity. Linguistically, these homogenous structures lead us from particular experiences (the observation that the right hand is strong/the left hand is weak in human activities), from a diachronic and diastratic perspective, to variable realizations, dispersed in the field of culture, religion, mentalities, and behaviour. They are loaded with ethics, religion, politics, economy, with the dynamic of history itself, etc. The subjective implications of body language, understood 
as a sine qua non condition in the formation of the individual on the scale of his ontological evolution are provided primarily by the human spirit and are strongly related to the concept of culture. Moreover, a modality to enhance the concept from individual entities to collective entities and, implicitly, a manner of approaching the personality from the perspective of the dynamics of manifestation and of cultural anthropology becomes functional. The language "of the hand" sets the vastest boundaries of manifestation of the dynamics of personality and of the implication into manifestation and to a less extent sets levels (conscious, subconscious), compartments (affective, cognitive, volitive) - these being part of the language of the "head", respectively of the "heart".

From among the words that named parts of the "body" - in the Graeco-Latin antiquity -, we take into consideration the Latin manus, a very productive lexeme as far as phrases are concerned, omnipresent through its semantics and vitality in most European languages. It is an element designating notions pertaining both to the common vocabulary and to biology, morals, army, authorities, mentalities, etc., being linked to material values, on the one hand, and to culture, on the other hand. The differences visible already in Latin are at the linguistic level; they are differences of representation and conceptualization: manus in the phrases per manus tractus, servatur (Caesar) - 'saved by being pulled by the hand' and traditae per manus religiones (Titus Livius) - 'beliefs transmitted from father to son' have not only different stylistic codes: manus appears in two contexts that do not have the same referent, do not illustrate the same concept, and do not preserve the same meaning but have a common prototypical "semantic denominator" (Angela Bidu-Vrânceanu). The first phrase names the sphere of manifestation of the human being, while the second names the field of mentalities. And this is not the only example: manus dextra and manus sinistra have a "bivalent" feature in the common vocabulary. That "something identical" is created from the given forms by the semantic link to a unique designatum at the Nomina Anatomica level. The information is extremely rich, and its sources are increasingly varied.

The purpose of the research hereby is not to thoroughly study the linguistic forms exclusively according to the criterion of dispersibility and diachronic evolution or the etymological matrix; it does not aim to define culture in itself or the strict meaning of independent linguistic entities but their vitality in the field of mentality and culture, in a system of relations arranged by "a semantic denominator". Although some of the specialized studies turned to the aspects regarding the invasion of the abstract notions of culture in the field of language - a situation that can isolate linguistics within the other disciplines of the humanities -, the task of anthropological linguistics is to analyse the objective and subjective implications of the language within a certain mentality and/or culture. Fundamentally, a prototypical "denominator..." develops the most varied meanings - claimed by the nature of the referent. The distributional properties 
of the noun manus, -us, for example, are semantically related to the contexts of conceptualization. In a minimal context, it is bivalent (Lat. manus dextra, Lat. manus sinistra).

Boas (Franz Boas 1990) has underlined the role the unconscious activity of the spirit has in the creation of language before Lévi-Strauss. The study of language was conceived as a paradigm for the analysis of all the other symbolic systems. Unconscious mental structures can be studied through language, through institutions - in the field of anthropology, just as language can be studied by relating it to the fields of mentality and culture -, in which it is reflected and which it reflects (besides the material forms), even if only partially.

Secondly, the systemic study of the dynamics of a prototypical "semantic denominator" becomes more prolific in related languages and cultures: the notion of instrument, the notion of mutualism - in the case of manus, the logical relation - at the level of Latin mentality, between manus and domus - the association with the feminine principle of governing the world, the symbolic feature, but, particularly the relation between the material and the spiritual established in the Latin tradition through a rhetoric of analogies are aspects we also find in the Romanic languages (and not only!). This type of systemic consubstantiality, semantic denominator, on the one hand, and language - dynamics of mentality -, culture, on the other hand, are maintained as subsidiary through several characteristic features.

The first feature would be the one theorized by modern anthropology (having application in the field of culture): transmissibility. It is a feature explicitly expressed by developing a series of statements - diachronically and diastratically distributed - in different fields of mentality and culture. Manus, - us was a countable noun of the $4^{\text {th }}$ declension, compatible with the grammatical opposition of singular/plural number and was part of the basic vocabulary. Although in the Latin language the nouns of the $4^{\text {th }}$ declension were usually masculine, manus is feminine, same as domus, -us (house). It had the following semantic features: part of the body/bi-positional/specific to man/instrument. In Latin, manum lavat (Seneca) reminds of the concrete circumstance of man's attitude towards himself, of self-respect, by the gesture without any ritual connotations of washing one's hands. Metaphors of right and left lateralities can have different (behavioural, religious) meanings from one linguistic variant to another but also from one cultural pattern to another. The pan-Latin vocabulary developed a value defined by mutualism: symmetrically, Rom. "o mână spală pe alta” (one hand washes another) - is a phrase of mutualism found also in the field of ethics and psychology but mainly in the field of group mentality. Being initially a plain phrase, it has become very expressive due to the contamination and shading of the meanings: Rom. “o mână spală pe alta”; It. "una mano lava l’altra”; Port. "uma mão lava a outra”, Sp. "Una mano lava la otra”. In French, "une main lave l'autre” 
- considered to originate from Plato's writings - became a proverb, and it has a profound lay, profane meaning. The phrase has been recorded in the documents of culture since the $19^{\text {th }}$ century and suggests the image of mutual help between similar parties: the right hand washes the left hand, while the left hand washes the right hand. At the same time, the image reminds of the circumstances of complicity, of the Pan-chronic solidarity of homo oeconomicus - for example, as far as both hands wash each other in a single gesture.

\section{Idioms and the cultural pattern}

The cultural pattern (with its numerous aspects) has a fundamental value in the study of comparative phraseology: phrases used by human communities sharing the same religion, for example, reflect the ethics generated by the dogma of that particular religion. In this context (of indestructible link between pattern and language), the language underlines - through its own means - the new meanings and senses demanded by the cultural context. (Claude Lévi-Strauss mentioned that "language can be considered as a basis, meant to sometimes have more complex structures, but of similar type to its own, which correspond to culture seen from different perspectives".) The reflexive form in the phrases: Rom. "a se spăla pe mâini" and Fr. "s`en laver les mains" (DEFR 1996) radically alters the perspective and the categories of representation by situating homo religiosus under the influence of the spiritual factor. The Holy Bible (Anania 2001) assigned the reference known in the entire Christian community as "wash one's hands" to Pontius Pilate: "So when Pilate saw that nothing was being gained, but rather a disturbance was starting, he took water, and washed his hands before the multitude, saying, 'I am innocent of the blood of this righteous person. You see to it'" (Matthew 27.24). The idea of moral cleansing is enhanced in the context in which the wise Roman judge understands that his interventions are useless against the resistance of Jesus's opponents. The analogical manner of expression could identify, in the absence of consensus in thinking and opinion - so much needed at the moment -, the paradigm of the super-individual pretext: the redemption, cleansing of his own conscience from sin. Pilate's repeated attempts to determine the opponent to respect certain values were unsuccessful, and this fact made it necessary to absolve himself from responsibility by a ritual gesture. Modern man moved the conceptual metaphor from the sphere of religion into that of other semantic denominators like: “a se spăla pe cap" (to wash one's hair) (meaning absolve oneself from responsibility). Such equivalent structures of free variation not only represent another level of human spirituality with a colloquial dimension but are also a sign of the desacralization of the mentality of modern man by alienating from religious behaviour. It can be noticed that the cultural 
pattern, on the one hand, and the semantic denominator, the verbal mark, on the other hand - no matter how well-established the phraseological units of a language may be -, if ungrammaticalized, contribute to the diastratic dynamics. From manum lavat to "one hand washes another", "to wash one's hands", and to "wash one's hair”, there is a diastratically marked and cultural hierarchy. It seems quite obvious that the first phrase has a neutral stylistic value (in the denotative register) unlike the structure "one hand washes the other" (in the connotative register). The phrase "to wash one's hair” is marked ironically, unappreciatingly (in the colloquial register), this stylistic colour being increasingly frequent in contemporary realizations of the phrase. Irony is emphasized by the nominal, atypical substitution opposed to a ritual-like behaviour of the person developed following the religious patterns of the Christian culture (from "to wash one's hands").

In order to go further in understanding the systemic relation between language and cultural pattern, it is necessary to determine the manner in which this correlation develops and to establish the differences: regarding the essence of the culture, technical achievements are less important than social, human, and religious determinations. The multiple features of the prototypical "semantic denominator" develop into a plurality of collateral realizations already starting with the Indo-European language. What seems to represent an identical denominator, an identical phrase from the linguistic point of view, is in fact identical neither in two different occurrences nor in two different compartments due to the dynamic of semantic features, on the one hand, and to the systemic relation between language and a particular cultural pattern, on the other hand.

\section{2. "The matrix"}

The types of manifestation, of implication or non-implication of an individual, mentality, etc. originate from a cultural pattern on the basis of which personality is formed. The parental (maternal/paternal/tutorial) cultural pattern is the "matrix", the psychological configuration called by Abraham Kardiner (Kardiner 1944) "the basic personality". The systemic relation between language and personality makes the social interaction between the individuals, between the human being and the other, objective. This is the context in which personality is defined as agglutination of roles and of personal applications of status to a social system through a varied typology of manifestation and pattern.

"The hand" has had an important role in defining personality through creative activities, a context in which "the semantic denominator" analogically developed various shades of meaning. In the tradition of Far Eastern languages, it implies the idea of - concrete or abstract, objective or subjective - activity, a feature also 
found in the Latin language and in the entire Roman mentality (DLR-Guțu, G. 2003): Lat. "portus manu facti" (Cicero) - Rom. "porturi create de mâna omului" (costumes created by the hands of man); "mea manu scriptae litterae" (Cicero) Rom. "scrisoare scrisă cu mâna mea" (letter written with my own hand), etc. The same perspective of the cultural anthropology can be taken into consideration in the case of other types of direct implications - Rom. "cu propriile mâini" "with one’s own hands', "lucru de mână” 'hand work', "broderie de mână" 'handmade embroidery' - or metaphoric implications of the "hand", while creating the works constituting a cultural heritage: Fr. "mettre la main à la pâte”( DEFR 1996) - to contribute to a work, Fr. "à voir avec leurs mains", etc.

Resemantization of idiomatic phrases related to the "hand" was performed also by simply considering the aspects of manifestation: hands are used for work but also to refuse activities: Rom. "a pune mâinile la treabă" (a începe să munceşti) (to put one’s hand to work (to start working)), "a pune mâna” (to put one’s hand into it), "a-şi face mâna" (a exersa, a se specializa) (have a hand for (to practise, to specialize in)) but also Rom. a sta "cu mâinile-n sân" (to sit with one’s hands in one’s lap, i.e. idly), "cu mâinile încrucişate" (with hands crossed), cu "mâinile la spate" (with one’s hands behind one’s back), cu "mâinile sus" (hands up), etc. The phrase "manum non vertere" (Cicero) 'a nu se sinchisi' (to not bother one's head about something) is also present in Romanian, but it implies a remodelling at the level of the semantic denominator. The metaphor Rom. "a nu mişca un deget" (to not lift a finger) has developed based on the concrete circumstance of refusing personal implication, of not stimulating subjectively/objectively a human activity/community. The cultural/mental pattern is significant through the power of suggestion. The categories of representations of the modern mentality moved the metaphor diachronically within the framework of other target fields (elements of the human body or of the environment): "a nu mişca un deget" (to not lift a finger), "a nu mişca un fir de păr" (to not move a hair's breadth), "a nu mişca un pai” (to not move a straw), "a nu mişca un fir de ață" (to not move a thread), "a sta cu mâinile în sân” (to sit with one’s hands in one’s lap), "a sta cu mâinile în buzunar" (to keep one's hands in one's pocket), etc. In diachronic synonymy, the Romanian language makes changes also at the level of initial meanings. On the same lexical basis "a nu mişca un deget" (to not lift a finger) can gain a value of trans-individual nature, especially in contemporary massmedia, where it contextually means not to be allowed to do anything without somebody's approval ("Petrescu's little soldiers do not lift a finger without first having the consent of their Romanian general”, Gazeta Sporturilor), the same as "a nu mişca un fir de ață" (to not move a thread) (a familiar phrase related to evidence in a case).

The metaphors "of the hand" create two opposing systems defining through two fundamental types of mentality, two types of personalities. What correlation 
is there between these two types of structuring of aspects, manifestations, human interactions, between the Indo-European languages which sometimes are so different? There is a correlation with the linguistic system and another with the manner of representation of two features of the prototypic semantic denominator: bivalence (right hand/left hand) and reciprocity. The metaphors "of the hand" create two opposing systems generated by this empirical "material" characterizing the ontology of the human. Habits, the attitude towards the environment and the objects within, towards the phenomena, the beings a mature man comes in contact with are absolutely relevant to the analysis of the denotative and connotative system of a language. As A. L. Kroeber (Kroeber 1948) said: "the hand" is a semantic pattern, a certain thinking and attitude pattern, reflected in its own terminology. This pattern has an internal logical connection, and, despite the fact that it obeys a conventional determination (through language), it is, on the one hand, the product of the primary impulse of man to relate to his own micro-universe - in the conceptualization process - and, on the other hand, a phrase of analogical and/or contrastive individual creativity, of the impulse toward ludens.

\section{3. "The initial language" (Plato) and the target field}

The primary cognitive patterns related to the manner in which the individual and the human communities relate themselves to the physical space, to the Cosmos, from the perspective of the right/left opposition, of the language "of the hand" (finger, phalanx, arm) cannot be dealt with disregarding the etymology the primary stratum of languages -, in terms of which Plato (Cratylos) thought there was "an initial language". The profound, metaphoric meanings of things, phenomena, and the being become one at this level.

The adjective "drept" (right) in the Romanian vocabulary with all its derivatives and phrases with a contextual referent containing this vocable has a positive connotation: "a călca cu dreptul” (to get off on the right foot), "a fi mâna dreaptă a cuiva" (to be the right-hand man), "a alege calea dreaptă” (to choose the right path), etc. As an absolute antonym, the adjective "stâng” (left) acquired deeply negative meanings: "a trage pe stânga" (to take to the left), "a călca cu stângul” (to get off on the wrong foot), etc. It is necessary to mention that problems regarding the right-left opposition are complicated in all the languages of Europe. In Latin, there were two separate words for all the concepts discussed here: on the one hand, the adj./noun dexter, -era, -erum and the adj. directus (derectus), perfect participle of the verb dirigo, -ere, -rexi, -rectum (to arrange in a straight line, to delineate (a special meaning)), to set a certain direction, to put it right), and, on the other hand, the adj./noun sinister, -tra, -trum (used with the meanings: "left" 
(sinistra manus), "unfavourable/ill-fated, bad" etc.) and the adj./noun laevus, -a, -um (left, from the left; stupid, silly; unfavourable, adverse, and so on). In French and Spanish, the adjectives "droit, -e" and "derecho/f. derecha" (originating just as the Romanian "drept" from the Latin directus (derectus)) have maintained positive connotations ("levez la main droite et dites 'je le jure"”) as opposed to "gauche" (ab initio, used with the meaning "weak"): "il confond sa droite et sa gauche", conferring value to the original semantics of the dichotomy. The variant "izquierda" also used to have the meaning of "crooked", "curved", "bent" in old Spanish. The noun "sinistra" (cf. Lat. sinister) took on in Italian the prototypical meaning of "left hand", "left part", while the adjective "sinistro" that of "left", "unfortunate event", "disaster". And there are many other examples. English uses the adj./ noun "left", which has - through etymon - the meaning of "weak", "worthless": "...so that left is for lyft, with the sense "worthless' or "weak" (Skeat 2007: 256). It can be observed from the given examples that the terms of the right-left opposition from the phrases rise through their "vision of the world" above the level of linguistic systems, no matter how fascinating these might be. Aspects referring to etymology are concurred with cognitive representations in Hungarian as well. Hungarian belongs to the Finno-Ugric group of languages. The ,jobb” (better) is used in expressions such as: "jobbra”, adv./to the right! (MRSZ 2005: 408), "jobb kéz"/right hand (MRSZ 2005: 448), "vkinek a jobbkeze vki”/ be someone's right hand (MRKK 2005: 133). The opposition of representation is realized with "bal”, adj., "left” (MRSZ 2005: 42): "bal kéz” (left hand), “ lábbal kelt fel"/get out of bed left foot forward/set your left foot first, "ne tudja a bal kéz, mit csinál a jobb"/the left hand doesn’t know what the right hand is doing (MRKK 2005: 20).

The issue to be discussed is what the mechanisms are by which the proposed opposition is maintained as a way of relating man to existence during different ages of the history of mankind: the pre-Roman period ("izquierda", a form inherited from the local pre-Roman vocabulary), the Roman period, the old German vocabulary (Fr. "gauche") and not only. Through what mechanisms do greatly lay categories become representations of the divine in somatic phraseologisms?

\section{References}

\section{Sources}

CDEE - Walter W. Skeat. 2007. Concise dictionary of English etymology. London: Wordsworth Editions Limited.

DEFR - Negreanu, Aristița. 1996. Dicționar de expresii francez-român. Bucharest: Editura Univers. 
DLR - Guțu, Gheorghe. 2003. Dicționar latin-român [Latin-Romanian dictionary]. $2^{\text {nd }}$ edition, revised and completed. Bucharest: Humanitas.

MRSZ - Abráhám, Piriska-Mariana, Popa et. al. 2005. Magyar-román szótár. Dicționar maghiar-roman. Carocom.

MRKK - Murvai, Olga. 2005. Magyar-román kifejezések kéziszótára. Dicționar maghiar-român de expresii. Sprinter Publisher.

\section{Theoretical references}

Bartolomeu, Valeriu Anania. 2001. Biblia sau Sfânta Scriptură. Bucharest: Institutul Biblic şi de Misiune al Bisericii Ortodoxe Române.

Boas, Franz. 1990. Anthropology and modern life. New York: Dover Publications. Kardiner, Abraham. 1944. Psychological frontiers of society. New York: Columbia University Press.

Kroeber, L. 1948. Anthropology: race, language, culture, psychology, prehistory. Harcourt, Brace \& World, Inc.: New York-Burlingame.

Strauss, Claude Lévi. 1998. Mythologiques, vol. I: Le cru et le cuit. Paris: Plon. 